\title{
Hedonic Motives and Fashion Trends in Decisions to Purchase Veil Clothes
}

\author{
Intisari Haryanti* \\ Institute of Economic Science of Bima \\ Bima, Indonesia \\ Intisariharyanti@gmail.com \\ Khas Sukma Mulya \\ Institute of Economic Science of Bima \\ Bima, Indonesia
}

\author{
Ita Purnama \\ Institute of Economic Science of Bima \\ Bima, Indonesia
}

Abstract - The current trend of veils being used at these days is the veil with long clothes, loose, and closed clothes that much resemble those worn by women in the old times. The changes not only occur in the veil model, but also buying behavior of consumers. The phenomenon that occurs today is consumers buying the goods which are not useful and not in accordance with needs. Consumers tend to buy the clothes to get recognition from others (hedonic motives) because the goods are in trend. The purpose of this study was to analyze the relationship between fashion trends and the hedonic motives of veil purchasing decisions by consumers. This research was conducted in Bima city, West Nusa Tenggara Province. Data were collected by using observation, questionnaires and literature studies with total sample of 96 people, chosen by using purposive sampling method. The results of this study indicate that fashion trends and hedonic motives affect the decisions to purchase of veil clothing in Bima city, both partially and simultaneously.

Keywords - hedonic motives, fashion trends, purchasing decisions

\section{INTRODUCTION}

In the old days, someone who wore a veil was often considered as not fashionable because it looked saggy. Some people assumed that the veil is only suitable for adults and older women, but the changing of times and development of technology has tremendously shifted the veil trend. Nowadays, young and old Moslem women change over to wear the veil. The veil that developed at this time is the veil with loose, long, and not tight clothing. Communities that wear fashionable veil are called hijabers. Nowadays, many hijabers communities tend to look fashionable and attractive as they keep up with the latest fashion developments. The development of the era and modern technology can influence the current veil trend so that it has big impact on the growth and development of culture, religion, and economy. This will definitely impact consumers' decisions in shopping. Shopping is also seen as a lifestyle of people in their daily lives and ends up as life necessities [1]. The reason women shop excessively is to spend time and money. In addition, women shop to eliminate boredom and entertain themselves. This often makes a person has a tendency to hedonic which tend to buy without prioritizing shopping priorities according to the needs, but for the self-pleasure [2], [3].

\author{
Nafisah Nurulrahmatiah \\ Institute of Economic Science of Bima \\ Bima, Indonesia
}

Nowadays, veil is not only an obligation for Muslim women, but the veil is also popular trend for teenagers in Bima city, even with loose veil model like the current trend. In the past, the veil was only a cloth used to cover the head, but now the veil model has changed a lot, from the veil by wearing a shirt that is paired with a skirt, wearing the veil with trousers, or the veil with a vest. Wearing a veil with long clothes that covers most part part upper body is called syar'i clothing.

The phenomenon of the veil that happened in Bima city today is wearing syar'i clothes. Not only old women but also teenagers are wearing syar'i clothing. Based on our interview, there are several factors that cause changes in fashion style, namely: the reason to migrate (hijrah), following the current fashions/trends, following friends around, feeling happy and calm, and also happy to get recognition on social media. In general, women in Bima city are wearing the veil during religious events such as recitation. The veil clothes are usually worn by old women, but nowadays, teenage woman and girls wear the veil in crowded places such as in markets, recreation areas, weddings, and other formal events.

Based on this phenomenon, researchers want to find out and analyze the influence of fashion trends and hedonic lifestyles on the decision to purchase the veil clothing in Bima city, both simultaneously and partially. This research is also expected to provide suggestion to the consumers, especially the veil wearer to be wiser in choosing products and purchasing decisions in accordance with the needs and benefits.

\section{LITERATURE REVIEW}

\section{A. Hedonist Motives}

The hedonic motive is an experience and sacrifice of consumers for getting an entertainment [4]. This experience includes the combination of expectations and emotions in the use of product [3]. The emotions that appear in the hedonist include feelings of pleasure, jealousy, fear, and anger. The hedonic shopping motives is the needs of someone to feel excited and happy [5]. The need for happy atmosphere creates enthusiasm, referring to the situation of someone feeling alert, excited, or active situation.

Hedonic motive was created from adventure, gratification, action, values, social, and ideas so that every 
individual has the potential to live in hedonic lifestyle [6][8]. Hedonic style is the situation where consumers urge themselves to purchase something without considering the usefulness or value of the product itself. No wonder if consumers who have high emotional will shop hedonically [3]. Hedonic motives will also appear from the passion for shopping, especially when during the launch of the latest models or version [8]. A hedonist who has positive emotions can buy the product without pre-planned or without shopping list records.

\section{B. Fashion Trend}

Fashion has means trends related to language style, behavior, hobbies towards certain clothing models that do not long-lasting [9]. Fashion has become an important part of the style, trends, and appearance of daily life, so fashion trend is something that develops in a society mostly in terms of fashion style. Thera are many reasons for consumers to follow the trend in the veil, such as preventing self from being outdated, for self-actualization, fulfill the inner needs, boost confidence and get recognition from others. This certainly has an impact on people's spending behavior that can create a new culture in society.

\section{Purchase Decision}

The purchase decision is the process of selecting two or more alternative choices [10]. There are six decisions that need to be organized by the buyer, namely: product choice, brand choice, the choice of seller, number of purchases, the right time to make a purchase and how to pay [11]. From the above definition, it can be concluded that the purchase decision is an action to choose from several existing alternatives and decided to buy.

\section{METHODS}

This research is an associative research that conducted in Bima city spreading in 5 districts, namely Raba, East Rasanae, Mpunda, West Rasanae, and Asakota districts. The population in this study are the people of Bima city in 5 districts. The sample collection was conducted by using purposive sampling technique with total of 96 people. It aims to determine the special characteristics in accordance with the objectives of the study so that it is expected to answer the research problems [12]. Data collectedfrom observation, questionnaires, and literature study. The instrument used in this study was questionnaire and the data in this research were analysed by using SPSS 22 for windows. The hypothesis in this study are:

H1 : Fashion trend influences the decision to purchase the veil clothing in Bima City.

H2 : Hedonist motives influence the decision to purchase the veil clothing.

H3 : Hedonic motive and fashion trend simultaneously influence the decision to purchase the veil clothing

\section{RESULTS}

Multiple linear regression analysis was used to determine the effect of fashion trends and hedonic motives on purchasing decisions. Then t-test is conducted by using SPSS version 22 for windows in order to know whether proposed hypothesis can be accepted or rejected. The following are the results of testing the hypothesis.

TABLE I. TEST RESULTS OF T

\begin{tabular}{|l|c|c|c|c|c|}
\hline \multirow{2}{*}{ Model } & \multicolumn{2}{|c|}{$\begin{array}{c}\text { Unstandardized } \\
\text { Coefficients }\end{array}$} & $\begin{array}{c}\text { Standardized } \\
\text { Coefficients }\end{array}$ & \multirow{2}{*}{$\mathrm{t}$} & \multirow{2}{*}{ Sig. } \\
\cline { 2 - 4 } & $\mathrm{B}$ & $\begin{array}{c}\text { Std. } \\
\text { Error }\end{array}$ & Beta & & \\
\hline Constant) & 9.374 & 2.341 & & 4.005 & .000 \\
\hline TOTAL T & .192 & .041 & .340 & 4.652 & .000 \\
\hline TOTAL H & .426 & .056 & .561 & 7.679 & .000 \\
\hline
\end{tabular}

\section{A. The Relationship between Fashion Trend and Purchasing Decisions}

Research on the influence of fashion trends on purchasing decisions (survey on female consumers at Boutique Ria Miranda in Branch Malang) explains that fashion trends give the character of the style and the color of fashion products which will be formed to be brought to the future [13]. According to them, fashion was a style that could be received by the majority of the group which has certain cycles of existence. It leads the market opinion and provide reference to the community that can be adopted and accepted by the consumers. This is supported by the results of this research which shows that the trend of fashions that are partial and simultaneous and has significant effect on the purchase decision of certain products. So it can be concluded that consumers can be affected by the trend of fashions in the decision to buy clothing products.

The results of the $t$ test statistic for variable trend fashion $(\mathrm{T})$ revealed $\mathrm{t}$ score of 4.652 with $\mathrm{t}$ table score of $1.985(4.652>1.661)$ with significance score of 0,000 less than $0.05(0,000<0.05)$, hence the first hypothesis $(\mathrm{H} 1))$ which states that fashion trend affects the decision to purchase the veil clothing in Bima city is "accepted". This finding supports the research [13]. The creation of new fashion style that is accepted by the market can be used as strategy to influence consumers in purchasing fashion products.

\section{B. The Relationship of Hedonic Motives in Purchase Decisions}

Consumers who shop with hedonic motives have the potential to do impulsive purchases because hedonic motives are based on adventure, satisfaction and emphasize elements such as "excitement" and "pleasure" [6]. Research on the effect of shopping motives on the decision to purchase used clothing in Pare Pare states that hedonist lifestyle is a psychological need such as satisfaction, prestige, emotions and other subjective feelings [14]. This needs often appear to fulfill social demands and aesthetic and hence called emotional motives. The results of the research led by Subagijo stated that the hedonic shopping motive has the most dominant influence on the decision to purchase used clothing in Pare-pare [14]. This corresponds to the hypothesis which states that the motive of hedonist's shopping is not only to buy goods but also for entertaining and socializing with 
friends. After shopping, the feeling of pleasure and satisfaction will be felt by consumers when getting good, branded, and affordable things. The results of the t-test statistics for the Hedonic Lifestyle variable $(\mathrm{H} 2)$ obtained $t$ value of 7.679 with the t table value of 1.985 (7.679 $<1.985)$ with a significance value of 0.000 less than 0.05 $(0.000>0.05)$. Thus, the hypothesis which states that "hedonic motifs influence the decision to purchase veil clothing in Bima city " is accepted ". This finding is in line with Gultekin and Fitriana in their research on the influence of Hedonic shopping motives on purchasing decisions which states that hedonic shopping motives has the most dominant influence on clothing purchase decisions. They said that consumers who go shopping without the intention to buy may be affected to buy when looking at items in the store [6], [14].

\section{The Relationship between Hedonic Motive and Fashion Trend Simultaneously to the Purchase Decisions.}

The relationship between hedonic motives, fashion trends and purchasing decisions is also explained in the study of the influence of hedonic lifestyles, fashion involvement and the environment in the store on impulsive purchases (study in Colorbox store consumers at Boemi Kedaton Mall, Bandar Lampung) which stated that the hedonic lifestyle, fashion and environmental involvement in the store had the influence to increase consumers to make impulsive purchases of COLORBOX stores at Boemi Kedaton Mall, Bandar Lampung [15]. The involvement variable mode is the variable that contributes the most dominant; hedonic lifestyle variable is variable that contribute moderately; and the environment variable in the store is the variable that contributes less. The results of testing the third hypothesis (H3) obtained significance from the $F$ test $(0.000<\alpha=0.05)$, and the $F$ value of 65.516 is greater than the $\mathrm{F}$ table $(65.516<)$, that means the $\mathrm{H} 0$ is rejected and $\mathrm{H} 1$ which states the Fashion Trend and Style Hedonis' life had a simultaneous influence on the decision to purchase hijab clothes in the city of Bima "accepted". This study supports the research [16].

\section{CONCLUSION}

Fashion trends and hedonic motives affect the decision to purchase the veil clothes in Bima city both simultaneously and partially. The consumers buy the veil clothes because they want to make themselves happy (hedonic benefits). It is proven by the score for trend which is not exceeding that of hedonic motive. However, there are few limitations of this study that should be note, namely: First, this research is focused on multiple regression analysis, where other analytical tools such as SEM analysis is suggestable. Second, this study does not use in-depth qualitative analysis to find out the reasons for the purchasing decision itself. Further research might also put cultural variables into account, since the culture of each region and place could lead to different analysis.

\section{REFERENCES}

M. J. Arnold and K. E. Reynolds, "Hedonic shopping motivations," J. Retail., vol. 79, no. 2, pp. 77-95, 2003.

[2] Fitriana, "Pengaruh Motif Belanja Terhadap Keputusan Pembelian Pakaian Bekas di Pare-pare," Econ. J., vol. 3, no. 1,

2015
B. GÃ¹/4tekin, "The influence of hedonic motives and browsing on impulse buying," J. Econ. Behav. Stud., vol. 4 , no. 3, pp. 180-189, 2012.

[4] M. B. Holbrook and E. C. Hirschman, "The experiential aspects of consumption: Consumer fantasies, feelings, and fun," J. Consum. Res., vol. 9, no. 2, pp. 132-140, 1982.

[5] N. Irani and K. H. Hanzaee, "The effects of variety-seeking buying tendency and price sensitivity on utilitarian and hedonic value in apparel shopping satisfaction," Int. J. Mark. Stud., vol. 3, no. 3, p. 89, 2011

[6] P. Kotler and K. L. Keller, "A framework for marketing management," 2007.

[7] E. F. Mufidah and P. S. D. Wulansari, "Gaya Hidup Hedonisme Mahasiswa Pascasarjana di Media Sosial," JKI (Jurnal Konseling Indones., vol. 3, no. 2, pp. 33-36, 2018.

[8] J. W. Overby and E.-J. Lee, "The effects of utilitarian and hedonic online shopping value on consumer preference and intentions," J. Bus. Res., vol. 59, no. 10-11, pp. 1160-1166, 2006.

[9] I. Haryanti and H. Nurdin, "Fashion Trends and Hedonic Lifestyle on Decisions Purchase of Hijab Dresses in Bima," $L i$ Falah J. Stud. Ekon. dan Bisnis Islam, vol. 4, no. 2, pp. 163174, 2020.

[10] N. D. S. J. AK, "PENGARUH GAYA HIDUP HEDONIS, KETERLIBATAN MODE DAN LINGKUNGAN DI DALAM TOKO TERHADAP PEMBELIAN IMPULSIF (Studi Pada Konsumen Toko COLORBOX Di Mall Boemi Kedaton Bandar Lampung)," 2018.

[11] L. Schiffman, "G.., Kanuk, L., L. 2000. Consumer Behavior," Am. Prentice Hall Int. Inc, 2004.

[12] D. A. Kosyu, "Pengaruh Hedonic Shopping Motives Terhadap Shopping Lifestyle dan Impulse Buying (Survei pada Pelanggan Outlet Stradivarius di Galaxy Mall Surabaya)," $J$. Adm. Bisnis, vol. 14, no. 2, 2014.

[13] Soerjono Sukanto, Kamus Sosiologi. Jakarta: Raja Graffindo, 2004.

[14] H. Subagio, "Pengaruh atribut supermarket terhadap motif belanja hedonik motif belanja utilitarian dan loyalitas konsumen," J. Manaj. Pemasar., vol. 6, no. 1, pp. 8-21, 2012.

[15] P. Sugiyono, "Metodologi penelitian kuantitatif kualitatif dan R\&D," Alpabeta, Bandung, 2011

[16] Sugiyono, No TitleMetode Penelitian kuantitatif, kualitatif dan $R \& D$. Bandung: Alfabeta, 2011. 